\section{А. О. Савич \\ ORCID https://orcid.org/0000-0001-6053-7625 \\ ResearcherID ABD-7342-2020 \\ Scopus Author ID 57219298635 \\ Л. В. Слободянюк \\ ORCID https://orcid.org/0000-0002-0400-1305 \\ ResearcherID AAM-4248-2021 \\ Scopus Author ID 57211311669 \\ С. М. Марчишин \\ ORCID https://orcid.org/0000-0001-9585-1251 \\ Scopus Author ID 6507637943}

Тернопільський національний медичний університет імені І. Я. Горбачевського МОЗ України

\title{
МЕТОДИЧНІ АСПЕКТИ ВИКЛАДАННЯ ВИБІРКОВОЇ ДИСЦИПЛІНИ «НУТРИЦІОЛОГІЯ» ДЛЯ СТУДЕНТІВ ФАРМАЦЕВТИЧНОГО ФАКУЛЬТЕТУ ДЕННОЇ ФОРМИ НАВЧАННЯ
}

\author{
A. O. Savych, L. V. Slobodianiuk, S. M. Marchyshyn \\ I. Horbachevsky Ternopil National Medical University \\ METHODOLOGICAL ASPECTS OF TEACHING THE SELECTIVE \\ DISCIPLINE “NUTRITIOLOGY” FOR STUDENTS OF \\ PHARMACEUTICAL FACULTY OF FULL-TIME FORM OF EDUCATION
}

\begin{abstract}
Анотація. У статті висвітлено шляхи вирішення основних проблем, з якими стикаються викладачі при підготовці фахівців другого (магістерського) рівня вищої освіти галузі знань 22 «Охорона здоров’я» під час викладання вибіркової дисципліни «Нутриціологія». Проаналізовано основні проблеми, які можуть впливати на результативність навчання студентів фармацевтичного факультету денної форми навчання зі спеціальності 226 «Фармація, промислова фармація». Дослідження базується на вивченні матеріалів, отриманих із відкритих джерел інформації та власного досвіду авторів. У статті наведені сучасні технології викладання та тестування студентів з дисципліни «Нутриціологія», впроваджені на кафедрі фармакогнозії з медичною ботанікою Тернопільського національного медичного університету імені І. Я. Горбачевського МОЗ України.

Метою викладання дисципліни «Нутриціологія» є формування системи знань і вмінь, які однозначно дадуть можливість майбутньому фахівцю фармацевтичної галузі повноцінно та якісно виконувати свої професійні обов’язки у сфері лікувальної нутриціології, й допоможе набути знання з виробництва, класифікації та сфери застосування дієтичних добавок і харчових продуктів функціонального та спеціального призначення.

Запропонований метод дозволяє викладачеві успішніше будувати освітній процес, що, в кінцевому підсумку, позитивно позначається на загальному засвоєнні курсу.
\end{abstract}

Ключові слова: нутриціологія; дієтичні добавки; спеціальні харчові продукти; функціональні харчові продукти; лікувальне харчування.

Abstract. The article highlights the ways to solve the main problems faced by teachers in the training of specialists of the second (master's degree) level of higher education in the branch of knowledge 22 "Healthcare" during the teaching of the selective course "Nutritiology". The main problems that may affect the effectiveness of full-time students of the Faculty of Pharmacy in the specialty 226 "Pharmacy, industrial pharmacy" are analyzed. The research is based on the study of materials obtained from open sources of information and the authors' own experience. The article presents modern technologies of teaching and testing of students in the discipline "Nutritiology", introduced at the Department of Pharmacognosy with Medical Botany of Ivan Horbachevsky Ternopil National Medical University Ministry of Health of Ukraine.

The aim of teaching the discipline "Nutritiology" is to form a system of knowledge and skills that will unambiguously enable the future specialist in the pharmaceutical industry to fully and efficiently perform their professional duties in the field of medical nutrition and help to acquire knowledge on production, classification and application of dietary supplements, functional and special foods. The proposed method allows the teacher to successfully build an educational process, which ultimately positively affects the overall mastering of the course.

Key words: nutritiology; dietary supplements; special foods; functional foods; medical nutrition.

( А. О. Савич, Л. В. Слободянюк, С. М. Марчишин 
Вступ. Якісна підготовка, перепідготовка та підвищення кваліфікації фармацевтичних кадрів є важливою складовою реформування галузі охорони здоров'я та реалізації соціальних пріоритетів держави, оскільки від рівня підготовки провізорів залежить якість надання медичної допомоги населенню країни. Нині вимоги до якісної професійної діяльності фармацевтичного працівника базуються на стандартах Директиви ЄС 2005/36/EC, до якої поступово адаптується й українське законодавство, а також система вищої фармацевтичної освіти, яка вимагає вдосконалення форм та методів навчання 3 метою оптимізації навчального процесу і підготовки конкурентоспроможних спеціалістів на ринку праці, що легко можуть адаптовуватися до сучасних вимог. Саме це зумовило необхідність переходу вищої школи до нової кредитно-модульної системи організації навчального процесу, що, у свою чергу, приведе до зростання інтелектуального та творчого потенціалу студентів.

Мета статті - вивчення методичних аспектів викладання вибіркової дисципліни «Нутриціологія» для студентів фармацевтичного факультету денної форми навчання зі спеціальності 226 «Фармація, промислова фармація».

Теоретична частина. Навчальна дисципліна «Нутриціологія» належить до вибіркових дисциплін циклу професійно-орієнтованої підготовки фахівців спеціальності 226 «Фармація, промислова фармація». Нутриціологія, як наука, базується на вивченні понять нутриціології, основних компонентів продуктів харчування, їх дії та взаємодії у підтриманні здоров’ я або виникненні захворювань, знайомить із вимогами до якості та виробництва дієтичних добавок [3, 5, 7].

Згідно з навчальним планом підготовки фахівців другого (магістерського) рівня вищої освіти галузі знань 22 «Охорона здоров’я», у Тернопільському національному медичному університеті імені I. Я. Горбачевського МОЗ України за спеціальністю 226 «Фармація, промислова фармація» освітньої кваліфікації «Магістр фармації» вивчення даної дисципліни здійснюється на 4-му курсі.

Мета викладання даної дисципліни передбачає сформувати систему знань і вмінь, які однозначно дадуть можливість майбутньому фахівцю фармацевтичної галузі повноцінно та якісно виконувати свої професійні обов’язки у сфері лікувальної нутриціології й допоможе набути знання з виробництва, класифікації та сфери застосування дієтичних добавок і харчових продуктів функціонального та спеціального призначення. Важливим аспектом у викладанні даної дисципліни є ознайомлення студентів-провізорів із термінологією, сировиною природного походження, яка використовується у виробництві дієтичних добавок (ДД), спеціальних харчових продуктів (СХП) та функціональних харчових продуктів (ФХП), компонентами продуктів харчування, їх дією і взаємодією, роллю у підтриманні здоров’я, створенням, аналізом та обгрунтуванням використання ДД, СХП та ФХП [2, 4, 8].

Основними завданнями вивчення дисципліни «Нутриціологія» $є$ засвоєння загальних питань нутриціології як спеціальної дисципліни у підготовці фахівця напрямку «Фармація»; засвоєння термінології з нутриціології; застосовування знань хімічного складу природної сировини у складі ДД, СХП та ФХП; використовування знань для пошуку джерел для створення нових ДД, СХП та ФХП і всебічної мобілізації природних ресурсів для потреб охорони здоров’я людини; засвоєння вимог до виробництва і методів аналізу ДД, СХП та ФХП; використовування методів аналізу ДД, СХП та ФХП у професійній діяльності; на основі знань хімічного складу сировини здатність визначати хімічні та фармакологічні несумісності компонентів ДД, СХП та ФХП та інших лікарських засобів; інформування щодо протипоказань ДД, СХП та ФХП; уміння надати професійну консультацію хворому і лікареві з питань використання і вибору ДД.

Під час викладання даної дисципліни закладаються теоретичні основи вивчення студентами-провізорами способів виготовлення спеціальних харчових продуктів (СХП) та функціональних харчових продуктів (ФХП) для різних категорій населення та осіб із порушеннями харчового статусу; способів удосконалення та розробки методів аналізу якості і безпеки ДД, СХП та ФХП; способів удосконалення системи контролю над виробництвом і реалізацією ДД, СХП та ФХП. На практичних заняттях студенти отримують вміння застосовувати характеристику ДД, СХП та ФХП у професійній діяльності; застосовувати знання хімічного складу сировини природного походження, що входить до складу ДД, СХП та ФХП; знаходити потенціальні та нові джерела есенціальних нутрієнтів; робити висновок про якість сировини на основі результатів фармакопейного аналізу; застосовувати знання з клінічних досліджень парафармацевтиків; створювати рекомендації з визначення оптимальних доз біологічно активних речовин (БАР) у складі ДД, СХП та ФХП; розробляти інформаційні листки, робити доповіді 
для лікарів і надавати консультації населенню 3 питань, пов'язаних із ДД, СХП та ФХП [3, 6, 7].

Детальне і грунтовне ознайомлення з основами вибіркової дисципліни «Нутриціологія» дає можливість більш повно засвоїти матеріал, що вивчається, реалізувати науково-творчий потенціал студентів, збагачує їх знаннями, які безпосередньо будуть використані в їхній практичній діяльності [3, 5, 7].

Для освоєння матеріалу виділено 12 год лекцій, 36 год практичних занять, 102 год самостійної роботи студентів. Така невелика кількість аудиторних годин вимагає від викладача дуже ретельного підходу до підбору навчального матеріалу та методики його викладання, яке включає велику кількість різноманітних прийомів, зокрема спілкування 3 викладачем на практичних, семінарських і лекційних заняттях, а також допомогу студентові при виконанні самостійної роботи.

Наочна демонстрація різних груп ДД, СХП, ФХП і схем лікувального харчування під час практичного заняття та детальне обговорення прикладів їх застосування, використавши теоретичні знання, значно підвищують якість засвоєння матеріалу. При вивченні даної дисципліни студентам читаються лекції з мультимедійним супроводом, які сприяють всебічному сприйняттю викладеного матеріалу та більш повному його засвоєнню. На лекцію студенти приходять підготовленими, оскільки матеріали підготовки до лекцій розміщені на Web-порталі університету в системі Moodle [1]. Практичні заняття з даної дисципліни проводяться згідно зі «стрічковою» системою, відповідно до якої студенти денної форми навчання мають 18 практичних занять та 6 лекцій. Під час вивчення дисципліни студенти розглядають такі теми практичних занять:

- Тема 1. Нутриціологія. Основні терміни і поняття. Визначення та мета нутриціології. Класифікація ДД, СХП та ФХП. Актуальність використання ДД, СХП та ФХП. Відмінності «ДД» і «харчових добавок». Критерії відмінності ДД від лікарських препаратів, класифікація ДД. Визначення понять «нутрицевтики», «парафармацевтики», «еубіотики». Вимоги до кожної категорії, особливості, класифікація, використання.

- Тема 2. Макронутрієнти як основа повноцінного харчування. Поняття про макронутрієти та їх класифікація. Функціональне призначення для організму людини. Регуляція обміну білків, жирів та вуглеводів. Природні джерела отримання макронутрієнтів та добова потреба в них для нормальної життєдіяльності організму людини.
- Тема 3. Мікронутрієнти як регулятори процесів життєдіяльності організму. Поняття про мікронутрієнти та їх класифікація. Основні функції мікронутрієнтів у забезпеченні нормальної життєдіяльності організму людини. Природні джерела отримання вітамінів, вітаміноподібних речовин, амінокислот, жирних кислот, мінеральних речовин. Добова потреба у мікронутрієнтах та захворювання, що виникають при їх дефіциті.

- Тема 4. Раціон. Раціональне харчування. Основні принципи раціонального харчування. Теорії харчування. Енергетична і харчова цінність раціону, енергетичні витрати людини при різних видах діяльності.

- Тема 5. Аліментарно-залежні захворювання. Лікувальне харчування, його особливості та показання. Аліментарно-залежні захворювання, їх поширення, фактори ризику та методи корекції. Види харчування. Лікувальне харчування, його особливості та показання.

- Тема 6. Харчовий статус, його види та методи оцінки. Збір анкето-опитувальних даних при вивченні харчового статусу. Методи визначення соматометричних показників як об'єктивне оцінювання харчового статусу та метод виявлення розладів харчування. Недоцільні поєднання харчових продуктів.

- Тема 7. Дієтичні добавки до їжі: особливості складу і застосування. ДД, їх класифікація, світовий ринок. Нормативно-правові документи, що регламентують статус ДД в Україні. Парафармацевтики та нутрицевтики, принципи їх використання. Пробіотики, їх класифікація та вплив на організм людини. Активні компоненти, що входять до складу ДД.

- Тема 8. Функціональні харчові продукти, їх основні компоненти та сфера застосування. ФХП, їх класифікація, ринок в Україні та світі. Нормативно-правові документи, що регламентують статус ФХП в Україні. Основні компоненти ФХП, сфера їх застосування. Вимоги щодо якості та безпечності продуктів харчування.

- Тема 9. Спеціальні харчові продукти, їх основні компоненти та сфера застосування. СХП, їх класифікація, ринок в Україні та світі. Основні компоненти СХП, сфера їх застосування. Вимоги щодо якості та безпечності спеціальних продуктів харчування.

Тема 10. Лікувальне харчування при цукровому діабеті. Цукровий діабет, його класифікація, фактори ризику в дітей та дорослих, симптоми. Основ- 
ні принципи лікування цукрового діабету. Поняття про глікемічний індекс. Лікувальне харчування при цукровому діабеті. Режим харчування, хімічний склад дієти та енергоцінність.

- Тема 11. Лікувальне харчування при ожирінні. Поняття про ожиріння, його ступені та причини виникнення. Методи визначення ступенів ожиріння. Способи корекції аліментарно-конституційного типу ожиріння. Лікувальне харчування при ожирінні. Режим харчування, хімічний склад дієти та енергоцінність.

- Тема 12. Лікувальне харчування при метаболічному синдромі. Метаболічний синдром, критерії діагностики, групи ризику щодо розвитку, основні принципи немедикаментозного лікування. Лікувальне харчування при метаболічному синдромі. Режим харчування, хімічний склад дієти та енергоцінність.

- Тема 13. Лікувальне харчування при виразковій хворобі та гастритах із порушенням секреторної активності. Найбільш поширені захворювання травної системи. Вплив їжі на функціональну активність ШКТ. Хімічний склад їжі. Основні принципи харчування при виразковій хворобі. Лікувальне харчування при захворюваннях ШКТ, що супроводжуються гіпер- та гіпоацидними станами.

- Тема 14. Лікувальне харчування при захворюваннях печінки, жовчного міхура та жовчовивідних шляхів. Основні принципи харчування при захворюваннях гепатобіліарної системи. Лікувальне харчування при захворюваннях печінки, жовчного міхура, жовчовивідних шляхів, панкреатиті. Режим харчування, хімічний склад дієти та енергоцінність.

- Тема 15. Лікувальне харчування при захворюваннях підшлункової залози. Основні принципи харчування при запальних захворюваннях підшлункової залози. Лікувальне харчування при хронічному панкреатиті. Режим харчування, хімічний склад дієти та енергоцінність.

- Тема 16. Лікувальне харчування при атеросклерозі. Атеросклероз як фактор ризику виникнення захворювань серцево-судинної системи. Баланс холестерину в організмі людини, його синтез та виведення. Шляхи зниження рівня холестерину в крові. Лікувальне харчування при атеросклерозі. Контроль маси тіла.

- Тема 17. Лікувальне харчування при серцево-судинній недостатності. Серцево-судинна недостатність, причини розвитку та методи профілактики. Харчування після перенесеного інфаркту міокарда, при ішемічній хворобі серця та хронічній серцевій недостатності. Дієтичні добавки при серцево-судинних захворюваннях.

- Тема 18. Лікувальне харчування при гіпертонічній хворобі. Гіпертонічна хвороба та її ускладнення. Особливості лікувальної дієти при гіпертонічній хворобі. Режим харчування, хімічний склад раціону та енергоцінність.

Кожне практичне заняття забезпечене методичними рекомендаціями, матеріалами підготовки до практичного заняття, тестовими завданнями для контролю знань, ситуаційними задачами та методичними вказівками для самостійної роботи студентів. Також для кожної теми заняття викладачі використовують реальні приклади з практичної фармації, пов’язані з вивченим теоретичним матеріалом, які студенти оформляють у робочі протоколи, де записують одержані результати та аналізують висновки. Системність ведення протоколів та дотримання вимог щодо їх оформлення враховується при комплексному підході оцінювання. У кінці семестру передбачено залік. Викладачі постійно працюють над удосконаленням необхідного навчально-методичного забезпечення дисципліни, прагнуть домогтися засвоєння знань, практичних навичок, сприяють формуванню наукового світогляду, моральних, естетичних та інших якостей особистості, вихованню колективу [1]. Також орієнтуються на потреби студента у певних знаннях, уміннях і навичках з опорою на подальшу самоосвіту, оскільки в навчальному закладі не закінчується формування особистості спеціаліста, воно продовжується все життя впродовж практичної діяльності і безперервного підвищення кваліфікації.

Висновки та перспективи подальших досліджень. Узагальнюючи вищесказане, «Нутриціологія» - це дисципліна, яка формує систему знань і вмінь, які однозначно дадуть можливість майбутньому фахівцю фармацевтичної галузі повноцінно і якісно виконувати свої професійні обов'язки 3 підбору та реалізації ДД, СХП та ФХП в аптечних закладах та рекомендацій щодо лікувального харчування при аліментарно-залежних захворюваннях. Під час викладання даної дисципліни закладаються теоретичні основи вивчення студентами способів виготовлення спеціальних та функціональних харчових продуктів для різних категорій населення та осіб з порушеннями харчового статусу, способів їх удосконалення та розробки методів аналізу якості і безпеки, а також способів удосконалення системи контролю над їх виробництвом і реалізацією. 
Аналіз та введення у педагогічну діяльність теоретично обгрунтованих сучасних положень, нових прийомів та методів дозволять студентам систематизувати отримані знання, практичні навички і їх використання у майбутній професійній діяльності.

Перспективи подальших досліджень вбачаємо в удосконаленні методик викладання дисципліни за вибором «Нутриціологія» для підготовки фахівців

\section{Список літератури}

1. Особливості функціонування системи внутрішнього забезпечення якості вищої освіти в Тернопільському національному медичному університеті імені І. Я. Горбачевського МОЗ України / М. М. Корда, А. В. Чорномидз, А. Г. Шульгай, А. І. Машталір // Медична освіта. 2020. - № 4. - C. 32-37.

2. Breemen R. B. Development of safe and effective botanical dietary supplements / R. B. Breemen // Journal of medicinal chemistry. - 2015. - Vol. 58 (21). - P. 8360-8372.

3. Davison K. M. Medical nutrition therapy in Canadian federal correctional facilities / K. M. Davison, C. D’Andreamatteo, V. L. Smye // BMC health services research. - 2019. - Vol. 19 (1). - P. 89.

4. Dwyer J. T. Dietary Supplements: regulatory challenges and research resources / J. T. Dwyer, P. M. Coates, M. J. Smith // Nutrients. - 2018. - Vol. 10 (1). - P. 41.

\section{References}

1. Korda, M.M., Chornomydz, A.V., Shulhai, A.H., \& Mashtalir, A.I. (2020). Osoblyvosti funktsionuvannya systemy vnutrishnoho zabezpechennya yakosti vyshchoyi osvity v ternopilskomu natsionalnomu medychnomu universyteti imeni I. Ya. Horbachevskoho MOZ Ukrayiny [Features of functioning of the system of internal quality assurance of higher education at I. Horbachevsky Ternopil National Medical University of Ministry of Health of Ukraine]. Medychna osvita - Medical Education, 4, 32-37 [in Ukrainian].

2. Breemen, R.B. (2015). Development of safe and effective botanical dietary supplements. Journal of Medicinal Chemistry, 58(21), 8360-8372.

3. Davison, K.M., D’Andreamatteo, C., \& Smye, V.L. (2019). Medical nutrition therapy in Canadian federal correctional facilities. BMC Health Services Research, 19(1), 89.

4. Dwyer, J.T., Coates, P.M., \& Smith, M.J. (2018). Dietary Supplements: regulatory challenges and esearch resources. Nutrients, 10(1), 41. другого (магістерського) рівня вищої освіти галузі знань 22 «Охорона здоров’я» у Тернопільському національному медичному університеті імені I. Я. Горбачевського МОЗ України за спеціальністю 226 «Фармація, промислова фармація» відповідно до вимог сучасного освітнього процесу та професійної діяльності майбутніх провізорів.

5. Medical nutrition therapy access in CKD: A Crosssectional survey of patients and providers / E. Y. Jimenez, K. Kelley, M. Schofield [et al.] // Kidney medicine. - 2020. Vol. 3 (1). - P. 31-41.

6. Nutrition therapy recommendations for the management of adults with diabetes / A. B. Evert, J. L. Boucher, M. Cypress [et al.] // American Diabetes Association. Diabetes care. - 2013. - Vol. 36 (11). - P. 3821-3842.

7. Nutritrauma: A key concept for minimising the harmful effects of the administration of medical nutrition therapy / J. C. Yébenes, L. Campins, I. Martínez de Lagran [et al.] // Nutrients. - 2019. - Vol. 11 (8). - P. 1775.

8. Sprouse A. A. Pharmacokinetic interactions between drugs and botanical dietary supplements / A. A. Sprouse, R. B. Breemen // Drug metabolism and disposition: the biological fate of chemicals. - 2016. - Vol. 44 (2). - P. 162171.

5. Jimenez, E.Y., Kelley, K., Schofield, M., Brommage, D., Steiber, A., Abram, J.K., \& Kramer, H. (2020). Medical nutrition therapy access in CKD: a cross-sectional survey of patients and providers. Kidney Medicine, 3(1), 31-41.

6. Evert, A.B., Boucher, J.L., Cypress, M., Dunbar, S.A., Franz, M.J., Mayer-Davis, E.J., ... Yancy, W.S., Jr. (2013). Nutrition therapy recommendations for the management of adults with diabetes. American Diabetes Association. Diabetes Care, 36(11), 3821-3842.

7. Yébenes, J.C., Campins, L., Martínez de Lagran, I., Bordeje, L., Lorencio, C., Grau, T., ... Serra-Prat, M. (2019). Nutritrauma: A key concept for minimising the harmful effects of the administration of medical nutrition therapy. Nutrients, 11(8), 1775.

8. Sprouse, A.A., \& Breemen, R.B. (2016). Pharmacokinetic interactions between drugs and botanical dietary supplements. Drug Metabolism and Disposition: the Biological Fate of Chemicals, 44(2), 162-171. 